\title{
SNS01-T Nanoparticles
}

National Cancer Institute

\section{Source}

National Cancer Institute. SNS01-T Nanoparticles. NCI Thesaurus. Code C98288.

A colloidal mixture of nanoparticles consisting of small interfering RNA (siRNA) targeting the native eukaryotic translation initiation factor 5A (elF5A), plasmids expressing a proapoptotic mutant of elF5A under the control of a B-cell specific promoter (B29), and a synthetic cationic polymer polyethylenimine (PEI) as a delivery vehicle, with potential antineoplastic activity. Upon administration, the siRNA component of SNS01-T suppresses elF5A expression, thereby interfering with translation of elF5A and reducing levels of hypusinated elF5A in cancer cells. In turn, this inhibits activation of the transcription factor NF-kB and induces apoptosis. In addition, the B-cell specific plasmid component expresses an arginine substituted form of elF5A, elF5AK50R, which can not be hypusinated, thus leads to a selective induction of apoptosis in B-cells. The native unhypusinated form of elF5A is pro-apoptotic and can be modified at the lysine residue, by deoxyhypusine synthase (DHS) and subsequently deoxyhypusine hydroxylase (DHH), to the anti-apoptotic hypusinated form which is associated with tumor cell growth and survival. The delivery vehicle protects the siRNA and plasmid from degradation. 